\title{
CRITERIA, INDICATORS AND LEVELS OF RESEARCH OF FUTURE TEACHERS' READINESS FOR ORGANIZATION OF DIALOGIC TEACHING FOR PRIMARY SCHOOL STUDENTS
}

\author{
KATERYNA FOMIN
}

\begin{abstract}
The article substantiates the necessity to study the criterion-content and level structure regarding the formation of readiness of future elementary school teachers to organize dialogic teaching. While creating the program of the experimental work the author has taken into account the basic postulations of psychological and pedagogical science, concerning the problem of the readiness of future specialists to organize dialogic teaching, professionalism of activity and communication and dialogic pedagogical communication. The article offers indicative criteria for studying the readiness of future elementary school teachers to organize dialogic teaching of students: need-motivational, cognitive, social-communicative, reflexive-value and operationalactivity, as well as indicators of their detection. The levels of readiness of future elementary school teachers to organize dialogic training are determined - high, medium and low.

The author presents the results of the empirical study of the state of students' readiness for dialogic teaching of primary school students according to the need-motivational criterion. The results of diagnostics of future teachers' motivation of achievement, understanding of their motivational structure of dialogic teaching, internal motivation of their readiness for selfdevelopment, resistance to external influences (in particular, results of ranking by the degree of importance of motives of future pedagogical professional activity) are presented. It is proved that the introduction into the process of training of primary school teachers of the author's model allows to change substantially the motivation of future specialists for future professional activity.
\end{abstract}

Keywords: dialogic teaching of primary school students, future teachers, levels of dialogic readiness, criteria and indicators of teacher's professional readiness for dialogic teaching.

\section{INTRODUCTION}

In today's context of integration into the global educational space, there is a need to introduce innovative approaches to the education of students in general secondary education, especially in elementary school. At present, the issues of interaction between participants of the educational process, pedagogy of partnership, the use of various forms and methods of active teaching of students are very relevant. Therefore, the problem of organizing dialogic teaching in elementary school requires careful study of innovative methods, including foreign experience.Issues of future teachers' training for pedagogical activity were investigated by: O. Antonova, V. Bondar, O. Budnyk, O. Dubaseniuk, N. Kichuk, L. Koval, L. Khomych, H. Vasianovych, M. Yevtukh, I. Ziazun, and others scientists. 
Educational dialogue as a way of organizing the educational process was studied by: L. Burman, V. Vyhrushch, L. Vovk, I. Glazkova, L. Kondrashova, V. Morozov, and others. However, the organizational framework for training teachers for the organization of dialogic teaching in elementary school using innovative tools in today's educational challenges (in particular, regarding the implementation of the New Ukrainian School reform) has not been adequately covered in previous research.

We consider future teachers' readiness for the organization of dialogic reaching as a complex dynamic formation, represented by the interaction of subjective (psychological and pedagogical qualities of the future teacher, the level of professional mastery of the future profession and the processes of professional self-development) and objective (educational environment) of reality and specified in theoretically substantiated criteria.

The aim of the articles to substantiate the criteria, indicators and levels of formation of future primary school teachers 'readiness for organizing students' dialogic education; present the results of an empirical study of the need-motivational component of this readiness.

\section{ANALYSIS AND Discussion}

For the empirical study, the criterion structure of future primary school teachers' readiness to organize dialogic teaching was determined. We proceed from the fact that the criterion (from the Latin criterium - "distinction") is a "measure for determining, evaluating an object, a phenomenon; an indication taken as a basis of classification" [3], "The basis for evaluating, defining or classifying something" [10, p. 465], a necessary and sufficient condition for the manifestation of a particular phenomenon or process, and the criterion approach to studying the level of readiness of future primary school teachers makes it possible to distinguish the levels of formation of this phenomenon at both personal and behavioral levels.

The criteria for the readiness of future teachers to organize dialogic education in primary school are considered as interrelated components, the presence and expression of which forms an appropriate level and can be diagnosed by certain indicators. Based on the classification of researchers $[1 ; 2 ; 4 ; 5 ; 6$; $7 ; 8 ; 9]$, we highlight the following criteria for the readiness of future elementary school teachers to organize dialogic teaching: need-motivational, cognitive, social-communicative, reflexive-value and operational-activity. Each of these criteria is a reflection of the holistic process of professional training of a future elementary school teacher, his / her professional development as an innovative specialist in the comprehensive school system, capable of self-actualization, self-motivation, value attitude to professional activity, partnership interaction with all subjects of educational process. The defined criteria are revealed through a system of empirical indicators that reflect the degree-level formation of the future primary school teacher's willingness to organize dialogic teaching.

While creating the program of the experimental work it is necessary to take into account the basic principles of psychological and pedagogical science, which relate to the problem of future specialists' readiness for the organization of dialogic training, professionalism of activity and communication and dialogic pedagogical communication. The article is based on the following guidelines.

First, the scientific achievements of scientists are more focused on clarifying the readiness components of future specialists of different specialties (A. Bystryukova, T. Tykhonova, P. Kharchenko, etc.). Most scholars distinguish interrelated components such as: motivational-willed, cognitiveintellectual, creative-activity, and others in the readiness structure.

Secondly, dialogic teaching is based on the basic principles and principles of dialogic communication, which are covered in scientific literature from the standpoint of certain aspects: sociophilosophical, cultural, methodological, psychological, pedagogical, etc. We have also taken into account the results of research on the nature and specificity of the dialogue revealed in the works of H. Ball, N. Basyuk, I. Beha, V. Vyhrushch, V. Kahn-Kalyk, O. Leontyev, O. Kyrychuk and others. Experimental work to study the readiness of future teachers to organize dialogic education in primary school was organized by us in certain stages, each of which was aimed at identifying certain indicators 
of manifestation and solving certain problems with the help of the selected psychodiagnostic tools. The main stages of the experimental work were the following: analytical, synthesis, ascertainment, formative, final and prognostic.

The purpose of the analytical-synthesis stage was to create a system of conceptual basis for the problem under study. The objectives of the ascertaining stage of the study were to empirically study the problem of future primary school teachers' readiness to organize dialogic teaching in real practice of professional training of future specialists of the educational institution by means of the criteriondiagnostic complex.

At the stage of forming experiment, the model of the readiness formation of future primary school teachers the verification took place according to the following criteria: cognitive, social-communicative, need-motivational, reflexive-value and operational-activity. The aim of the final prognostic phase was to develop systematic and methodological recommendations for the introduction of technology for the formation of future primary school teachers 'readiness to organize students' dialogic education.

Selecting the sample of subjects, we took into account the general specificity of the subject under study. The research was carried out at the pedagogical faculties of Vasyl Stefanyk Precarpathian National University, Pereyaslav-Khmelnytsky State Pedagogical University named after Hryhoriy Skovoroda and the Faculty of Pedagogical Education and Social Work at Lesya Ukrainka Eastern European National University. The total sample size is 294 future primary school teachers.

The purpose of the pedagogical experiment was to test the author's model of creating the readiness of future primary school teachers to organize dialogic teaching.

The substantive characteristics of the criteria, indicators and levels of formation of future primary school teachers' readiness for the organization of dialogic teaching and the approximate scheme of the experimental study are presented in Table 1 and 2.

\begin{tabular}{|c|c|c|c|}
\hline 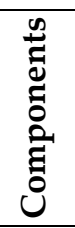 & 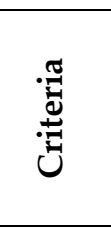 & Indicators & Diagnostic methods \\
\hline$\sum_{\substack{: \\
0}}^{0}$ &  & $\begin{array}{l}\text { Readiness for learning, transmission of } \\
\text { information on the nature and specifics of } \\
\text { the organization of dialogic teaching in } \\
\text { primary school }\end{array}$ & $\begin{array}{c}\text { Author's Questionnaire "Willingness to } \\
\text { organize dialogic teaching at primary } \\
\text { school" }\end{array}$ \\
\hline 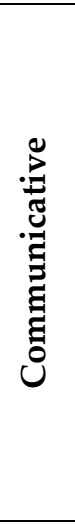 & 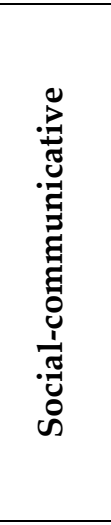 & $\begin{array}{l}\text { Level of need for communication; } \\
\text { evaluation of communication and } \\
\text { organizational skills; total level of empathy. }\end{array}$ & $\begin{array}{l}\text { Author's questionnaire "Willingness to } \\
\text { organize dialogic teaching at primary } \\
\text { school"; test "Need for communication" } \\
\text { (Y. Orlov, V. Shkurkin, L. Orlova); } \\
\text { methodology of assessment of } \\
\text { communicative and organizational } \\
\text { abilities (KOZ-2); test for professional } \\
\text { and pedagogical communication skills } \\
\text { (by V. Kan-Kalik, N. Nikandrova); } \\
\text { method of diagnostics of the level of } \\
\text { empathic abilities (V. Boyko) }\end{array}$ \\
\hline 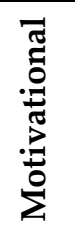 & Z & $\begin{array}{l}\text { Having needs for self-development, } \\
\text { attitudes and sustainable motives for } \\
\text { success; domination of intrinsic motivation }\end{array}$ & $\begin{array}{l}\text { Author's questionnaire "Willingness to } \\
\text { organize dialogic teaching at primary } \\
\text { school"; method of diagnostics of } \\
\text { motivation of professional activity } \\
\text { (K. Zamfir in modification of A. Rean) }\end{array}$ \\
\hline
\end{tabular}




\begin{tabular}{|c|c|c|c|}
\hline 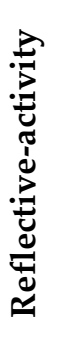 & 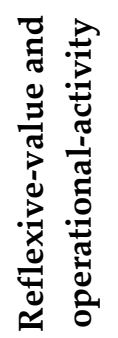 & $\begin{array}{l}\text { value orientation of the person on } \\
\text { interaction, partnership, cooperation; self- } \\
\text { development level; professional and } \\
\text { pedagogical competence }\end{array}$ & $\begin{array}{l}\text { Author's questionnaire "Willingness to } \\
\text { organize dialogic teaching at primary } \\
\text { school"; M. Rokych's method "Value } \\
\text { orientations"; L. Berezhnov's method of } \\
\text { diagnostics of the level of self- } \\
\text { development and professional- } \\
\text { pedagogical activity }\end{array}$ \\
\hline
\end{tabular}

Tab. 1. Scheme of experimental study of the formation of future primary school teachers' readiness for organization of dialogic teaching

\begin{tabular}{|c|c|c|}
\hline Criteria & Indicators & Quality level characteristic of formation of the criteria of readiness \\
\hline \multirow{3}{*}{ 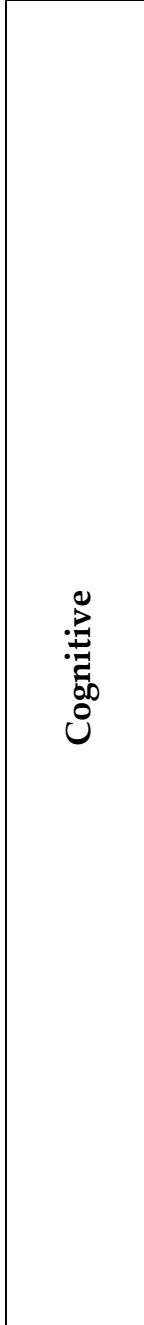 } & \multirow{3}{*}{$\begin{array}{l}\text { Awareness of the } \\
\text { cognitive sphere of a } \\
\text { personality; awareness of } \\
\text { the psychological features } \\
\text { of the cognitive processes } \\
\text { development of the } \\
\text { primary school child; } \\
\text { ways to influence the } \\
\text { cognitive sphere of the } \\
\text { primary school child; } \\
\text { personal cognitive } \\
\text { competence; knowledge } \\
\text { of the nature and ways of } \\
\text { organizing the primary } \\
\text { school development } \\
\text { environment }\end{array}$} & $\begin{array}{l}\text { High level - the student possesses a profound knowledge of the } \\
\text { theory of didactics; systematic knowledge of general, age and } \\
\text { pedagogical, social psychology, is aware of the need for new } \\
\text { approaches in the theory and practice of education and training; deep } \\
\text { and systematic theoretical knowledge about the peculiarities of the } \\
\text { development of the cognitive sphere of the individual; has } \\
\text { knowledge and techniques of influencing the cognitive sphere of the } \\
\text { child; skillfully promotes the development of cognitive qualities of } \\
\text { the student's personality; possesses learning ability and intellectual } \\
\text { ability; has a high level of information technology and personal } \\
\text { competence }\end{array}$ \\
\hline & & $\begin{array}{l}\text { Intermediate level - partial knowledge of the theory of didactics; } \\
\text { unsystematic knowledge of general, age and pedagogical, social } \\
\text { psychology, is aware of the need for new approaches in the theory } \\
\text { and practice of teaching and upbringing; partial knowledge about } \\
\text { features of development of cognitive sphere of personality; possesses } \\
\text { knowledge and techniques of influencing the cognitive sphere of the } \\
\text { child; an inherent conscious desire to master the means of influencing } \\
\text { the development of the cognitive qualities of the student's } \\
\text { personality; possesses learning ability and intellectual ability; has a } \\
\text { partial level of information technology and personal competence }\end{array}$ \\
\hline & & $\begin{array}{l}\text { Low level - available superficial psychological and pedagogical } \\
\text { knowledge about cognitive sphere of personality, ignorance of } \\
\text { methods of development of cognitive qualities and knowledge of } \\
\text { cognitive interest of primary school students, lack of practical skills } \\
\text { of positive pedagogical influence on the cognitive sphere of } \\
\text { elementary school students; does not have sufficient information } \\
\text { technology and personal competence }\end{array}$ \\
\hline 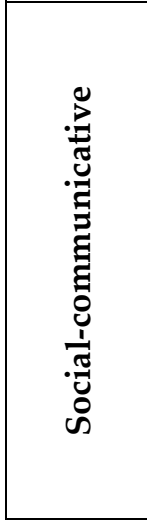 & $\begin{array}{l}\text { Communicative and } \\
\text { organizational skills; the } \\
\text { need for communication; } \\
\text { empathy; professional } \\
\text { and pedagogical } \\
\text { communication skills }\end{array}$ & $\begin{array}{l}\text { High level - definitely formed skills to establish dialogic forms } \\
\text { of interaction with students, combination and application of various } \\
\text { interactive forms of education and upbringing of primary school } \\
\text { students; adherence to pedagogical tact; willingness to receive } \\
\text { feedback; openness to interaction, dynamism and flexibility in } \\
\text { implementing organizational forms; empathy-sensory perception of } \\
\text { interaction; social-perceptive, communicative, interactive abilities, } \\
\text { social adaptability, social lability; ability for transformative activity, } \\
\text { innovative perception of reality, desire for search and transformation, } \\
\text { dynamism; ability to extra-situational activity; willingness to } \\
\text { understand the student, the ability to take his/her side in }\end{array}$ \\
\hline
\end{tabular}




\begin{tabular}{|c|c|c|}
\hline Criteria & Indicators & Quality level characteristic of formation of the criteria of readiness \\
\hline & & $\begin{array}{l}\text { communication; availability of individual-pedagogical style of } \\
\text { communication and professional activity }\end{array}$ \\
\hline & & $\begin{array}{l}\text { Intermediate level - partially formed ability to establish dialogic } \\
\text { forms of interaction with students, ability to traditional didactic } \\
\text { forms of education and upbringing of primary school students; } \\
\text { adherence to pedagogical tact; poor willingness to receive feedback; } \\
\text { rigidity in implementing organizational forms; partially expressed } \\
\text { social-perceptive, communicative, interactive abilities, social } \\
\text { adaptability, social lability; poor ability to transform, ability to } \\
\text { imitate and reproduce. }\end{array}$ \\
\hline & & $\begin{array}{l}\text { Low level - insufficiently formed skills for organizing interactive } \\
\text { forms of teaching; propensity for monologue speech; lack of } \\
\text { individual-pedagogical style of communication and professional } \\
\text { activity; low levels of empathy and reflection; social rigidity; ability } \\
\text { to reproduce }\end{array}$ \\
\hline \multirow{3}{*}{ 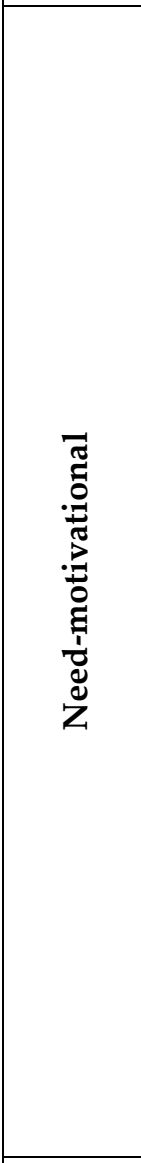 } & \multirow{3}{*}{$\begin{array}{l}\text { Achievement motivation; } \\
\text { understanding the } \\
\text { motivational structure of } \\
\text { dialogic teaching; intrinsic } \\
\text { motivation for self- } \\
\text { development; resistance } \\
\text { to external influences }\end{array}$} & $\begin{array}{l}\text { High level - the student has a strong internal motivation to achieve; } \\
\text { high level of readiness for improvement and self-development; the } \\
\text { desire to learn new forms and methods of organizing dialogic } \\
\text { teaching; ability to create situations of success in the process of } \\
\text { pedagogical activity; ability to understand the final result of the } \\
\text { activity; high goal-setting ability; readiness for continuous } \\
\text { improvement and self-development }\end{array}$ \\
\hline & & $\begin{array}{l}\text { Intermediate level - the student has a partial internal motivation to } \\
\text { achieve; high level of readiness for improvement and self- } \\
\text { development; the desire to learn new forms and methods of } \\
\text { organizing dialogic teaching; ability to create situations of success in } \\
\text { pedagogical activity; understands the final result of the activity; high } \\
\text { goal-setting ability; readiness for continuous improvement and self- } \\
\text { development }\end{array}$ \\
\hline & & $\begin{array}{l}\text { Low level - the student makes erroneous steps in professional } \\
\text { activity due to insufficient development of volitional qualities; in } \\
\text { complex emotionally intense situations, he/she is often unable to } \\
\text { mobilize and focus on the process of achieving a goal; admits the } \\
\text { manifestation of negative emotions and feelings in the process of } \\
\text { performing pedagogical functions; no sense of satisfaction from } \\
\text { professional activity; there is a negative impact of excessive } \\
\text { emotionality on the quality of teaching; in stressful situations can not } \\
\text { control his/her own behavior, prone to conflict; is guided only by } \\
\text { external stimuli in pedagogical activity. }\end{array}$ \\
\hline 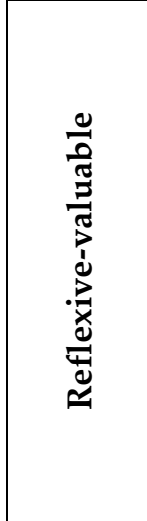 & $\begin{array}{l}\text { Awareness of the } \\
\text { importance of dialogic } \\
\text { teaching; the ability to } \\
\text { occupy a subject-subject } \\
\text { position; readiness for } \\
\text { self-development; } \\
\text { perception of participants } \\
\text { in the educational process } \\
\text { as carriers of values; } \\
\text { psychological and } \\
\text { pedagogical skills of self- }\end{array}$ & $\begin{array}{l}\text { High level - availability of deep and systematic theoretical } \\
\text { psychological and pedagogical knowledge and self-knowledge and } \\
\text { self-exploration of one's own experiences and emotional reactions; } \\
\text { the presence of the developed skills of self-correction and elimination } \\
\text { of negative cognitive, emotional, interactive displays of } \\
\text { organizational forms of dialogic teaching; the ability to properly } \\
\text { perform self-analysis of one's own professional behavior; high } \\
\text { interest in acquiring practical skills of dialogic self-regulation of } \\
\text { professional activity, sustainable focus on self-improvement and } \\
\text { partnerships in the organization of the educational process; ability to } \\
\text { accurately determine the nature of emotional states of participants }\end{array}$ \\
\hline
\end{tabular}




\begin{tabular}{|c|c|c|}
\hline Criteria & Indicators & Quality level characteristic of formation of the criteria of readiness \\
\hline & \multirow{3}{*}{$\begin{array}{l}\text { knowledge, self-study of } \\
\text { their own communicative } \\
\text { displays, causes and } \\
\text { consequences of the } \\
\text { introduction of certain } \\
\text { organizational forms of } \\
\text { dialogic teaching }\end{array}$} & $\begin{array}{l}\text { in the educational process, possession of a set of necessary } \\
\text { knowledge and skills to support the positive student's emotions and } \\
\text { feelings; skills of humane, tolerant attitude to others; display of } \\
\text { kindness, compassion and empathy; formed ability to penetrate into } \\
\text { the "inner world" of the student, identify with him or her, mastering } \\
\text { the basics of facilitation. }\end{array}$ \\
\hline & & $\begin{array}{l}\text { Intermediate level - partial inclination for introspection and self- } \\
\text { correction of his or her own style of dialogical communication, ability } \\
\text { to organize problematic dialogic training; emotional experiences in } \\
\text { professional activity; awareness of the need for development and } \\
\text { self-improvement of volitional qualities; introspection and analysis of } \\
\text { the results of individual pedagogical activity his or her own behavior } \\
\text { and emotional manifestations in the pedagogical process; shows } \\
\text { sufficient activity and interest in acquiring knowledge, skills and } \\
\text { abilities of emotional and volitional regulation of professional } \\
\text { activity; strives to improve readiness for professional self- } \\
\text { development. }\end{array}$ \\
\hline & & $\begin{array}{l}\text { Low level - insufficient knowledge and partially formed ability of } \\
\text { self-knowledge of his or her own ability to organize dialogic } \\
\text { education in elementary school; lack of self-correction skills for } \\
\text { personal and professional experiences; displays of inadequate } \\
\text { response in professional activity; inability to self-analyze and analyze } \\
\text { behavioral manifestations in pedagogical interaction; indifferent } \\
\text { attitude to self-education and self-improvement; indifferent, biased } \\
\text { attitude towards students, lack of knowledge about individual and } \\
\text { psychological features of students, low level (or complete absence) of } \\
\text { empathy. }\end{array}$ \\
\hline 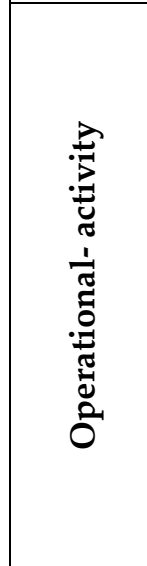 & $\begin{array}{l}\text { Ability to apply } \\
\text { innovative and interactive } \\
\text { technologies for the } \\
\text { organization of dialog } \\
\text { learning; understanding } \\
\text { of goals, assessment of } \\
\text { pedagogical situation, } \\
\text { flexibility of decision- } \\
\text { making, mastery of } \\
\text { pedagogical skills }\end{array}$ & $\begin{array}{l}\text { High level - possession of innovative and interactive technologies for } \\
\text { organization of dialogic training at creative and professional level; } \\
\text { high flexibility and predictability in decision making. } \\
\text { The middle level is the use of innovative and interactive } \\
\text { technologies at the reproductive-adaptive level, insufficient } \\
\text { awareness of the possibilities of application and introduction of } \\
\text { forms and methods of dialogical learning, partial readiness for self- } \\
\text { improvement. } \\
\text { Low level - insufficient possession of innovative and interactive } \\
\text { technologies for the organization of dialogic training, dependence, } \\
\text { passivity in decision-making, poor self-analysis of his or her own } \\
\text { professional capabilities. }\end{array}$ \\
\hline
\end{tabular}

Tab. 2. Criteria, indicators and levels of students' readiness to organize dialogic education in primary school

Let us study in details the status and changes of the levels of formation of motivational readiness component of future teachers to organize dialogic teaching at primary school from the point of view of need-motivational criterion. In the course of experimental work, their motivation, understanding of the motivational structure of dialogic teaching, the intrinsic motivation of their readiness for selfdevelopment, resistance to external influences were diagnosted. For this purpose, the author's questionnaire "Willingness to organize dialogic teaching at primary school" and K. Zamfir's method of diagnostics of professional activity motivation (A. Rean's modification) were used.

In particular, students were encouraged to rank the importance of their future pedagogical professional activity skills by significance degree. The data obtained during the questioning process showed that prior to carrying out the procedures that involved the design phase of the experiment, in 
both CG (control group) and EG (experimental group), prospective primary school teachers were mainly focused on meeting their own professional needs. This is evidenced by the fact that high ranks have received such motives as "to achieve the desired status in society", "the opportunity to succeed in professional activity", "to satisfy own needs for communication", "being able to be a leader in the educational environment among students"; "awareness of oneself value" (Figs. 1, 2).

Forming dialogic motivational setting for.

Receive joy from communicating with..

Apply digital teaching technologies

Effort to form a dialogic style of. Meet all students' needs

Success in communication and interaction

Awareness of one's own value Meet parents' need for a teaching profession

Efforts to improve financial situation

Professional growth and improvement

Experiencing positive emotions while..

Opportunity to be a leader in the..

Meet own communication needs

The ability to succeed in careers

To achieve the desired status in society

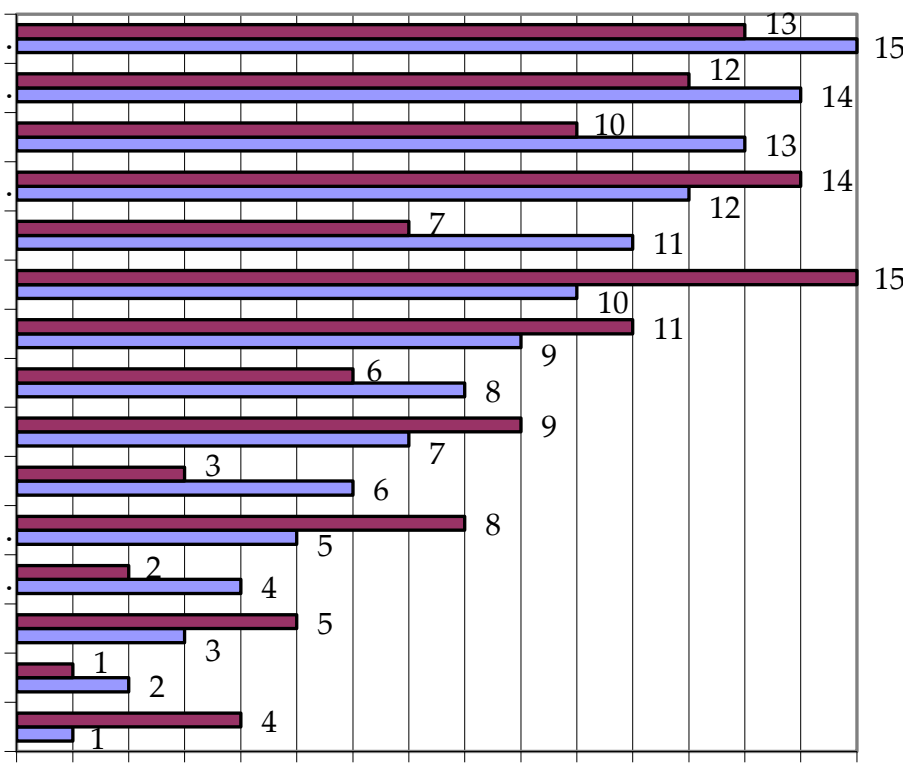

$\begin{array}{llllllllllllllll}0 & 1 & 2 & 3 & 4 & 5 & 6 & 7 & 8 & 9 & 10 & 11 & 12 & 13 & 14 & 15\end{array}$

$\square$ After experiment $\square$ Before the experiment

Fig. 1. The results of ranking by CG their motives for future professional activity

Get satisfaction from the process of..

Experiencing positive emotions while..

Apply digital teaching technologies Success in communication and interaction Forming dialogic motivational setting for..

Efforts to improve financial situation Meet all students'needs Meet parents' need for a teaching profession

Effort to form a dialogic style of..

To achieve the desired status in society

Meet own communication needs

The ability to succeed in careers

Awareness of one's own value

Opportunity to be a leader in the.

Professional growth and improvement

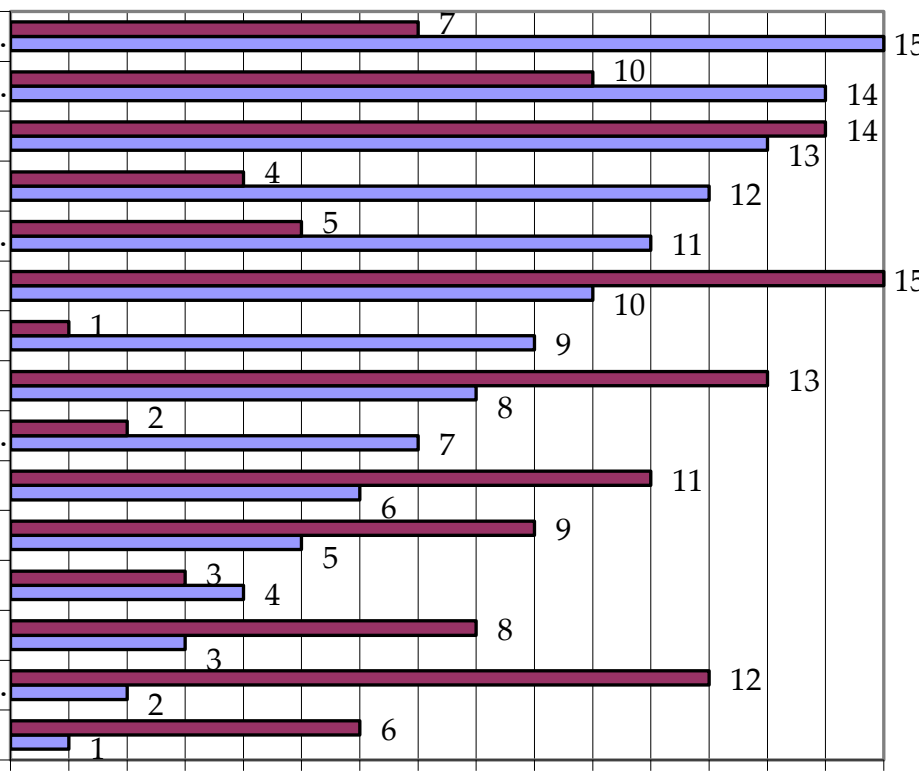

$\begin{array}{llllllllllllllll}0 & 1 & 2 & 3 & 4 & 5 & 6 & 7 & 8 & 9 & 10 & 11 & 12 & 13 & 14 & 15\end{array}$

After experiment $\square$ Before the experiment

Fig. 2. The results of ranking by $E G$ their motives for future professional activity 
After forming experiment for CG respondents, the above mentioned motives for professional activity remained dominant, although there was some regrouping in importance. Therefore, it can be argued that students' attitudes toward self-centered interests have not changed.

In the EG group, after the introduction of the approaches we have developed for training teachers for organization of students' dialogic education, there were significant changes in the students' motivation for professional activity. The highest ranks obtained such motives for professional activity as: "to meet all students' needs", "efforts to form a dialogic style of organization of the educational process", "the opportunity to succeed in professional activity", "success in communication and interaction", "developing a dialogic motivational setting for communication". Thus, in the motivational sphere of EG students there was a shift of emphasis towards understanding the importance of those motives for professional activity, which provide the most optimal development trajectory for the student, which is realized in the process of effective subject-subject interaction of the teacher and students in the process of dialogic teaching.

It should be noted that the motive "the opportunity to succeed in professional activity", which we refer to a group of motives that characterize a high level of student's motivation for future professional activity, occupies a rather important place in the hierarchy of students' motives both in CG (before the experiment - rank 2, after - rank 1) and EG (before the experiment - rank 4, after - rank 3). However, we believe that the nature of such an assessment of the importance of this motive by the students of CG and EG is different. In our opinion, the CG students consider its importance in the context of career growth, achievement of the desired status in society, improvement of financial status, because these motives received high ratings in their ratings both before and after the experiment. After the experiment, EG students assigned these motives grades 11 and 15, respectively. It indicates that they associate the opportunity to succeed in their professional activities with the satisfaction of their own mercantile interests, but with the professional realization of himself or herself as a specialist, a master of his/her field, capable of successfully carrying out the education and upbringing of younger generation.

\section{CONCLUSIONS}

In order to study the readiness of future primary school teachers to organize pupils' dialogic teaching, we recommend you to focus on the following assessment criteria and indicators for identifying them:

- need-motivational (the availability of needs for self-development, attitudes and sustainable motives for success; domination of intrinsic motivation);

- cognitive (readiness for mastering, transmission of information about the features and specifics of organization of dialogic education in primary school);

- social and communicative (level of need for communication; assessment of communicative and organizational skills; total level of empathy);

- reflexive-value and operational-activity (value-oriented personality for interaction, partnership, cooperation; level of self-development; professional-pedagogical competence).

In the study, we determined the level of readiness of future primary school teachers to perform in a particular context - high, medium and low.

After conducting our pedagogical experiment, a statistical evaluation of the revealed changes in the CG and EG students 'distributions by the need-motivational criterion of future teachers' readiness for organizing dialogic teaching of elementary school students showed that, that the changes that occurred in the CG are random and in the EG are statistically reliable. (Table 3). 


\begin{tabular}{|c|c|c|c|c|}
\hline Indicator & 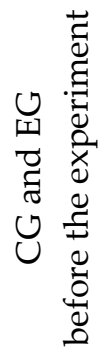 & 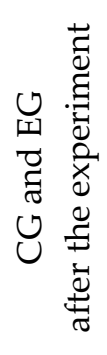 & 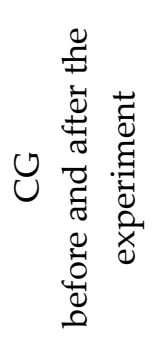 & 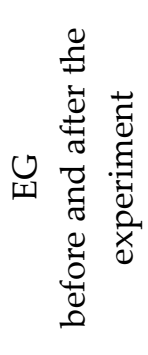 \\
\hline Self-assessment of motives for future professional activity & 1,393 & 6,192 & 0,886 & 14,972 \\
\hline
\end{tabular}

Tab. 3. Empirical values of the criterion $\chi^{2}$ calculated on the basis of data from the distribution of future primary school teachers by the level of formation of the indicator of vocational training for the organization of students' dialogical education

* Differences in distributions are considered statistically reliable if the ratio is:

$$
\chi_{\mathrm{e}}^{2}>\chi_{\mathrm{k}}^{2}
$$

This confirms the effectiveness of the experimental work.

Thus, the introduction of the suggested model into practice allows to change the motivation of future specialists for future professional activity significantly. In our opinion, this kind of motivation will allow them to successfully put into practice the basic principles of students' dialogic teaching, and, that will allow them to introduce the modern paradigm of education and upbringing of the younger generation into the New Ukrainian School.

\section{REFERENCES}

[1] Budnyk O. Motivation of Students to the Professional Pedagogical Activities. Scientific Bulletin of Chetm. Section of Pedagogy, 1 (2018), 53-63. Available at: http://yadda.icm.edu.pl/yadda/element/ bwmeta1.element.desklight-be55418b-854b-4b62-9d82-75a65bd087ac

[2] Kolb D.A. Experiential learning: Experience as the Source of Learning and Development. Prentice-Hall, Englewood Cliffs, NJ, 1984.

[3] The criterion. Slovopedia. Dictionary of foreign words by Melnychuk. Available at: http://slovopedia.org.ua/42/53402/284752.html (in Ukrainian)

[4] Littleton K., Howe Ch. (Eds.) Educational Dialogues: Understanding and Promoting Productive Interaction. Routledge, London, 2010.

[5] Major L., Kershner R. (Eds.) A Dialogue About Educational Dialogue: Reflections on the Field and the Work of The Cambridge Educational Dialogue Research (CEDiR) Group. 2018. Available at: http://www.academia.edu/37916282/A_Dialogue_About_Educational_Dialogue_Reflections_on_the_Fi eld_and_the_Work_of_The_Cambridge_Educational_Dialogue_Research_CEDiR_Group

[6] Maksymenko I.G. Dialogue training as a condition of humanization of pedagogical activity. Pedagogy of Higher and Secondary Education, 35 (2012), 230-236. Available at: https://journal.kdpu.edu.ua/pedag/ article/view/3538 (in Ukrainian)

[7] Maslow A. Motivation and personality. 3rd edition. Pyter, St. Petersburg, 2008. (in Russian)

[8] Matvienko O.V. Theoretical and methodological bases of training of future teachers for pedagogical interaction in the educational environment of primary school. Dissertation for the degree of Doctor of the Pedagogical Sciences: 13.00.04. Kyiv, 2010. (in Ukrainian)

[9] Muhonen H., Rasku-Puttonen H., Pakarinen E., Poikkeus A.-M., Lerkkanen M.-K. Knowledge-building patterns in educational dialogue. International Journal of Educational Research, 81 (2017), 25-37. doi: 10.1016/j.ijer.2016.10.005 
[10] Busel W. (Ed.) The Great Interpretive Dictionary of Modern Ukrainian. "Perun", Kyiv, Irpin, 2005. (in Ukrainian)

Address: Kateryna Fomin, Vasyl Stefanyk Precarpathian National University, 57, Shevchenko Str., IvanoFrankivsk, 76018, Ukraine.

E-mail: aerosweett@ukr.net

Received: 20.12.2019; revised: 05.02.2020.

Фомін Катерина. Критерії, показники та рівні дослідження готовності майбутніх учителів до організації діалогічного навчання молодших школярів. Журнал Прикарпатського університету імені Василя Стефаника, 7 (1) (2020), 112-121.

У статті обгрунтовано необхідність дослідження критеріально-змістової та рівневої структури щодо сформованості готовності майбутніх учителів початкової школи до організації діалогічного навчання. У розробці програми експериментальної роботи автором ураховано основні положення психодого-педагогічної науки, що стосуються проблеми готовності майбутніх фахівців до організації діалогічного навчання, професіоналізму діяльності і спілкування та діалогового педагогічного спілкування. У статті запропоновано орієнтовні критерії вивчення готовності майбутніх учителів початкової школи до організації діалогічного навчання учнів: потребово-мотиваційний, когнітивнопізнавальний, соціально-комунікативний, рефлексивно-ціннісний та операційно-діядьнісний, а також показники їх виявлення. Визначено рівні готовності майбутніх учителів початкової школи до організації діалогічного навчання - високий, середній і низький.

Автором представлено результати емпіричного дослідження стану сформованості готовності студентів до діалогічного навчання молодших школярів за потребово-мотиваційним критерієм. Подано результати діагностики сформованості в майбутніх учителів мотивації досягнень, розуміння ними мотиваційної структури діалогічного навчання, внутрішньої мотивації їх готовності до саморозвитку, стійкості до зовнішніх впливів (зокрема, результати ранжування за ступенем значущості мотивів майбутньої педагогічної професійної діяльності). Доведено, що впровадження в практику підготовки вчителя початкової школи авторської моделі дозволяе істотно змінювати мотивацію майбутніх фахівців до майбутньої професійної діяльності.

Ключові слова: діалогічне навчання молодших школярів, майбутні вчителі, рівні готовності до діалогічного навчання, критерії та показники професійної готовності вчителя до діалогічного навчання. 